$17^{\text {th }}$ International Congress of Metrology, 05002 (2015)

DOI: $10.1051 /$ metrology $/ 201505002$

(C) Owned by the authors, published by EDP Sciences, 2015

\title{
Traceable measurement of total organic carbon, TOC
}

\author{
Jeanett Norrbohm Sørensen ${ }^{1 \mathrm{a}}$ and Klaus Liljegren ${ }^{1}$ \\ ${ }^{1}$ Novo Nordisk, Krogshøjvej 51, 2800 Bagsverd, Denmark
}

\begin{abstract}
Résumé. La mesure du taux de Carbone Organique Total, COT, est utilisée pour évaluer la pureté de l'eau dans l'industrie pharmaceutique. Quelques pharmacopées imposent des exigences de test d'adéquation du système (SST), mais il n'y a aucune demande concernant la qualité de l'étalonnage ou de la mesure, et il est rare que l'incertitude d'étalonnage soit indiquée. Cette présentation décrit l'incertitude de l'étalon de COT et la pratique actuelle pour l'étalonnage de l'équipement de COT. Les résultats d'une comparaison entre 14 instruments seront présentés et comparés aux exigences actuelles. L'analyse des étalons disponibles et le résultat de la comparaison devraient mener à une description des méthodes pratiques d'étalonnage pour l'équipement de COT à Novo Nordisk.
\end{abstract}

\section{Introduction}

Measurement of Total Organic Carbon, TOC, is part of the method documenting the purity of water.

Several pharmacopoeias (e.g. the US and the European pharmacopoeia) set requirements to the system suitability (SST), but there are no requirements to the quality of the calibration or the measurement.

SST is performed by measuring solutions of sucrose, $r_{s}$, 1,4-benzoquinone, $\mathrm{r}_{\mathrm{ss}}$, and the TOC water, $\mathrm{r}_{\mathrm{w}}$, used producing the two solutions. Sucrose solution is easy to oxidize and benzoquinone more difficult. The relation, called response efficiency, gives a number for the ability of the instrument to measure TOC.

$$
\text { Response efficiency }=\frac{100 \cdot\left(r_{S s}-r_{w}\right)}{r_{s}-r_{w}}
$$

Novo Nordisk uses TOC instruments and standards from more than four manufacturers. Traceability is a GMP requirement; therefore we need to evaluate the traceability our TOC measurements.

\section{Calibration and SST}

In Novo Nordisk we use TOC instruments from mainly 4 manufacturers. For calibration and SST we use standards from:

- Altus Science

- ERA

- Mettler-Toledo, Thornton

- Novo Nordisk QC laboratories

- $\quad$ Sievers, GE

Looking at older calibration documentation, both one, two- and three-points calibrations have been used depending of the type of instrument, and some instruments make a linearity test, based on one KHP solution.

In Novo Nordisk instruments are normally calibrated traceable and in at least three calibration points.
Historical calibration data showed that SST results depended on manufacturer of both instrument and SST standards.

Often errors were negative indicating either a systematic error in standards or a limitation in the ability of the TOC instruments to oxidize the solutions; 22 measurements of 1,4-benzoquinone, $500 \mathrm{ppb} \mathrm{C}$, from three manufacturers using three different instruments gave an average error of $-70,7 \mathrm{ppb}$ with a standard deviation of \pm 69 $\mathrm{ppb}$.

The stated uncertainty for 1,4 Benzoquinone standards is in the range $1-8 \%$, that is $5-40 \mathrm{ppb}$.

Using the recipe for SST solutions stated in the pharmacopoeias the uncertainty can be as large as $12 \%$ depending on the quantity produced; this introduces a challenge as the requirement to $\mathrm{SST}$ is $\pm 15 \%$.

Two suppliers of calibration services in Denmark now states uncertainty of calibration; for our production plants outside Denmark we still look for ways to get same information.

\section{Proficiency test}

To get an overview of the variations that may influence a TOC result a proficiency test is performed in June/July. The test includes 14 instruments of the brands:

- Anatel

- Mettler-Toledo, Thornton

- Shimadzu

- $\quad$ Sievers, GE

SST-kits were used for the comparison, as these could be measured using existing procedures and thereby reflect the operating situation as much as possible. The SST solutions represent two types of solution and they are available with a stated uncertainty from an accredited supplier. The results and evaluation of the proficiency test will be presented at the conference.

\footnotetext{
a jnos@novonordisk.com
} 